\title{
Kebosanan Kerja Sebagai Prediktor Perilaku Cyberloafing Pada Karyawan
}

\author{
Fatiya Halum Husna \\ Institut Agama Islam Negeri (IAIN) Tulungagung \\ Ika Adita Silviandari, Ika Rahma Susilawati \\ Universitas Brawijaya,Malang
}

\begin{abstract}
Internet using in Indonesia has a rapid increase and encourages the misuse of internet using at a workplace named cyberloafing behavior. Work boredom is one crucial factor in increasing cyberloafing behavior. This study was aimed to determine the job boredom role as a predictor employee's cyberloafing behavior. This research used a quantitative approach. Questionnaires used to collect data about job boredom and cyberloafing behavior and analyzed by a simple regression method. The subjects are 114 administrative employees using a cluster sampling method. The analysis result showed a significance value $(p<0,05)$. It means the hypothesis from this research accepted that job boredom has a role as a predictor of cyberloafing behavior on $X$ university's employees. The data result explained that job boredom gives influential contributions as much as 11,1\% towards cyberloafing behavior. The study showed that job boredom as a significant variable for predicting employee's cyberloafing behavior.
\end{abstract}

Keywords: cyberloafing; employee; boredom; job; behavior; university.

\begin{abstract}
Abstrak
Penggunaan internet di Indonesia mengalami perkembangan yang pesat dan mendorong penyalahgunaan penggunaan internet di tempat kerja yaitu perilaku cyberloafing. Kebosanan kerja disebut menjadi salah faktor pendorong perilaku cyberloafing. Tujuan penelitian ini untuk melihat peran kebosanan kerja sebagai prediktor perilaku cyberloafing pada karyawan. Penelitian ini menggunakan pendekatan kuantitatif. Data penelitian dikumpulkan menggunakan skala kebosanan kerja dan skala perilaku cyberloafing. Analisis data menggunakan teknik analisis regresi sederhana. Jumlah subjek penelitian adalah 114 karyawan administratif yang diambil dengan metode cluster sampling. Hasil dari uji hipotesis menunjukkan nilai signifikansi $0.000(\mathrm{p}<0.05)$, hipotesis dari penelitian ini diterima, artinya kebosanan kerja secara signifikan berperan sebagai prediktor perilaku cyberloafing pada karyawan di Universitas X. Kontribusi variabel kebosanan kerja dalam memengaruhi variabel perilaku cyberloafing yaitu sekitar 11.1 persen. Implikasinya bahwa variabel kebosanan kerja layak untuk dipertimbangkan dalam memprediksi perilaku cyberloafing pada karyawan.
\end{abstract}

Kata kunci: Cyberloafing; Karyawan; Kebosanan; Kerja; Perilaku; Universitas. 
Penggunaan internet di Indonesia mengalami perkembangan yang pesat dimana tiap tahunnya jumlah pengguna internet terus meningkat (KOMINFO, 2014). Survei lain yang dilakukan oleh Baidu Indonesia yang dimuat pada situs online id.techinasia.com pada tahun yang sama menemukan bahwa 36 persen pengguna internet mengakses internet di tempat kerja (Kartika, 2014). Hasil Survei Asosiasi Penyelenggara Jasa Internet Indonesia (APJII) tahun 2017 menunjukkan bahwa 43.89 persen masyarakat menggunakan internat dengan durasi 1-3 jam perhari(KOMINFO, 2017). Masih di survei yang sama hampir 65.98 persen menyebutkan bahwa mengakses internet setiap hari. Saat ini pun, hampir sebagian besar tempat kerja memberikan fasilitas internet bagi karyawannya baik berupa jaringan internet melalui kabel LAN (local area network) maupun jaringan internet wifi.

Penyediaan internet di perusahaan atau organisasi sering kali disalahgunakan oleh karyawan untuk kepentingan-kepentingan lainnya seperti menerima e-mail pribadi, melakukan belanja online, membuka situs-situs berita, bahkan membuka situs dewasa (Hawley, 2005).Liberman. Seidman, McKenna, dan Buffardi (2011) menyatakan bahwa karyawan yang merasa bosan saat bekerja cenderung lebih mungkin untuk melakukan cyberloafing. Karyawan menggunakan computer perusahaan yang telah memiliki jaringan internet untuk melakukan cyberloafing seakan-akan sedang mengerjakan pekerjaannya (Askew dkk., 2014). Lim(2002)mengartikan cyberloafing sebagai kegiatan penyalahgunaan internet yang dilakukan oleh karyawan yang menggunakan jaringan internet perusahaan mereka pada saat jam kerja untuk berselancar di situs yang tidak terkait dengan pekerjaan untuk kepentingan pribadi dan memeriksa (termasuk didalamnya menerima dan mengirim) email pribadi.

Lim dan Teo (2005)membagi tipe perilaku cyberloafing menjadi 2 (dua) yaitu emailing activity dan browsing activity dimana pada penelitian ini mengacu pada tipe perilaku cyberloafing tersebut.Menurut Ozler dan Polat (2012) terdapat 3 (tiga) faktor yang menyebabkan perilaku cyberloafing yaitu faktor individual, faktor organisasi, dan faktor situasional. Salah satu dari faktor organisasi adalah karakteristik pekerjaan yakni perilaku cyberloafing muncul ketika karyawan bosan terhadap pekerjaannya. Cara untuk menghilangkan rasa bosan terhadap pekerjaannya adalah dengan mengalihkan perhatian dengan menggunakan internet untuk kepentingan yang tidak berkaitan dengan pekerjaan. 
Menurut Fisher (1993) dan Munandar(2011) pekerjaan-pekerjaan yang berulang dan monoton dapat menyebabkan seorang karyawan mengalami kebosanan. Kebosanan kerja merupakan keadaan di mana individu memiliki semangat yang rendah dan ketidakpuasan yang merupakan hasil dari lingkungan kerja yang tidak menstimulus karyawannya(Reijseger dkk., 2012; Schaufeli \& Salanova, 2014). Menurut Hooff dan Hooft(2017) kebosanan kerja juga dapat diakibatkan kurangnya identitas tugas, otonomi kerja yang rendah, signifikansi tugas yang rendah, serta kecilnya umpan balik pada pekerjaan yang sudah dilakukan. Aspek-aspek kebosanan kerja yang menjadi acuan dari penelitian ini adalah aspek-aspek menurut (Reijseger dkk., 2012) yang terdiri atas aspek afektif, kognitif, dan behavioral.

Terdapat berbagai dampak yang ditimbulkan ketika karyawan mengalami kebosanan kerja. Hasil penelitian Harju, Hakanen, dan Schaufeli (2014) menyatakan bahwa karyawan yang mengalami kebosanan kerja memiliki keinginan untuk melakukan turnover dua kali lipat lebih besar dibandingkan karyawan yang tidak mengalami kebosanan kerja. Kebosanan kerja juga dapat menurunkan kepuasan dan komitmen karyawan, meningkatkan intensi turnover dan perilaku kontra produktif (Mael \& Jex, 2015). Selain itu Eastin, Glynn, dan Griffiths(2007) menyatakan bahwa karyawan yang mengalami kebosanan kerja pada level yang tinggi akan terdorong untuk menunjukkan perilaku PWU (Personal Web Usage) dibandingkan karyawan yang merasa pekerjaan mereka menantang. Perilaku cyberloafing ini kemudian dijadikan sebagai salah satu strategi coping karyawan dalam menghadapi kebosanan akan pekerjaan yang monoton (Pindek, Krajcevska, \& Spector, 2018).

Adanya fasilitas internet yang disediakan oleh perusahaan dapat karyawan dapat mengalihkan perhatiannya dengan mengakses internet untuk kepentingan yang tidak berkaitan dengan pekerjaan tanpa harus meninggalkan meja kerjanya seperti membuka media sosial, berbelanja online, membuka situs berita, atau sekedar membuka dan mengirim email pribadi (Lim \& Teo, 2005). Askew, Buckner, Taing, Ilie, Bauer, dan Coovert (2014)menjelaskan bahwa karyawan menggunakan komputer perusahaan yang telah memiliki jaringan internet untuk melakukan cyberloafing seakan-akan sedang mengerjakan pekerjaannya.

Penelitian ini melibatkan subjek yaitu tenaga kependidikan bidang administrasi di Universitas X sebagai subjek penelitian. Ketertarikan ini berdasarkan Workforce Boredom Index 
(WBI) yang didapatkan dari survei Training and Development Agency for School (TDA) pada tahun 2006 dimana ditemukan bahwa karyawan administratif merupakan karyawan dengan tingkat kebosanan paling tinggi dibandingkan dengan karyawan dibidang lainnya dimana dari skala nilai 1 hingga 10 nilai kebosanan karyawan administratif memiliki nilai 10 (Berry, 2006). Selain itu, peneliti telah melakukan observasi sebelumnya di Universitas $X$ dan menemukan bahwa banyak tenaga administrasi yang mengakses situs-situs yang tidak berkaitan dengan pekerjaan pada saat jam kerja.

Berdasarkan keterkaitan antara variabel bebas dan variabel terikat diatas peneliti mengasumsikan bahwa perilaku cyberloafing pada karyawan dipengaruhi oleh kebosanan kerja yang dialaminya. Jadi, ketika karyawan mengalami kebosanan terhadap pekerjaan maka mereka akan mencari kegiatan lain yaitu menggunakan internet perusahaan untuk kepentingan pribadi yang tidak berkaitan dengan pekerjaan yang disebut perilaku cyberloafing. Tujuan dari penelitian ini adalah untuk mengetahui peran kebosanan kerja sebagai prediktor perilaku cyberloafing pada karyawan di Universitas X. Adapun hipotesis dari penelitian ini adalah "kebosanan kerja secara signifikan dapat berperan sebagai prediktor perilaku cyberloafing pada karyawan di Universitas X".

\section{Metode}

Penelitian ini menggunakan desain penelitian kuantitatif dengan mempertimbangkan tujuan dari penelitian ini yaitu untuk menguji hipotesis yang telah ditentukan secara general pada suatu populasi atau sampel. Variabel yang terlibat dalam penelitian ini yaitu kebosanan kerja dan perilaku cyber loafing. Kebosanan kerja adalah keadaan dimana individu memiliki semangat yang rendah, kurang berkonsetrasi, dan perasaan tidak puas akibat dari lingkungan kerja yang tidak menstimulus yang terdiri atas aspek afektif, kognitif, dan behavioral. Keadaan tersebut ditandai dengan adanya rasa tidak bersemangat dalam bekerja, tidak tertarik dengan pekerjaan, salah dalam mempersepsikan waktu, sulit berkonsentrasi, dan perilaku mengobrol dengan rekan kerja, serta melakukan kegiatan yang tidak berkaitan dengan pekerjaan. Kebosanan kerja diukur dengan menggunakan skala kebosanan kerja yang terdiri atas aspek afektif, kognitif, dan behavioral. 
Perilaku cyber loafing merupakan kegiatan penyalahgunaan jaringan internet perusahaan berupa penggunaan internet perusahaan untuk kepentingan pribadi yang tidak berkaitan dengan pekerjaan yang dilakukan oleh karyawan pada saat jam kerja. Hal tersebut ditandai dengan adanya penggunaan komputer perusahaan maupun alat elektronik pribadi seperti laptop, tablet, dan smartphone yang terkoneksi dengan jaringan wifi perusahaan yang terdiri atas emailing activity dan browsing activity. Perilaku tersebut diukur dengan menggunakan skala perilaku cyber loafing yang terdiri atas aspek emailing activity dan browsing activity.

Jumlah subjek sebanyak $114($ Laki-laki $=69$; Perempuan $=45)$ tenaga kependidikan bagian administrasi di Universitas $X$ yang diambil berdasarkan perhitungan menggunakan rumus Slovin dari total keseluruhan 1.885 karyawan. Peneliti memilih subjek yaitu tenaga kependidikan bagian administrasi yang mana terdiri atas bagian akademik, bagian kemahasiswaan dan alumni, bagian keuangan dan kepegawaian, serta bagian umum dan perlengkapan. Teknik pengambilan sampel yang digunakan adalah metode cluster sampling dimana dari 15 fakultas yang ada terpilih 7 fakultas yang diambil dengan sistem undian.

Skala yang digunakan sebagai alat ukur dalam penelitian ini telah melewati proses penyusunan yang valid dan reliabel. Adapun nilai reliabilitas dari skala kebosanan kerja dilihat dari nilai Cronbach's Alpha $=0.856$ dengan jumlah 21 butir pernyataan. Skala perilaku cyber loafing memiliki nilai Cronbach's Alpha sebesar 0.857 dengan 15 butir pernyataan. Data yang terkumpul kemudian dianalisis untuk menguji hipotesis penelitian. Analisis data dari penelitian ini menggunakan analisis regresi linier sederhana dengan bantuan aplikasi SPSS 20.0 for Windows yang mana sebelum dilakukan uji hipotesis peneliti terlebih dahulu melakukan uji asumsi klasik meliputi uji normalitas, uji linieritas, dan uji heterokedatisitas.

\section{Hasil}

\section{Deskripsi Subjek Penelitian}

Pada penelitian ini sebanyak 114 karyawan tenaga kependidikan bagian administrasi di Universitas X menjadi subjek penelitian. Berikut data demografis subjek penelitian: 
Tabel 1

Data Demografis Subjek Penelitian

\begin{tabular}{llcc}
\hline Data Demografis & \multicolumn{1}{c}{ Kategori } & $\Sigma$ & $\mathbf{\%}$ \\
\hline Jenis Kelamin & Laki-laki & 69 & $61 \%$ \\
& Perempuan & 45 & $39 \%$ \\
\hline Total & & $\mathbf{1 1 4}$ & $\mathbf{1 0 0 \%}$ \\
\hline Usia & $20-29$ & 37 & $32.45 \%$ \\
& $30-39$ & 37 & $32.45 \%$ \\
& $40-49$ & 22 & $19.29 \%$ \\
& $50-57$ & 13 & $11.40 \%$ \\
& Tidak diketahui & 5 & $4.38 \%$ \\
\hline Total & & $\mathbf{1 1 4}$ & $\mathbf{1 0 0} \%$ \\
\hline Bagian Kerja/ & Administrasi & 16 & $14 \%$ \\
Divisi & Akademik & 17 & $15 \%$ \\
& Kemahasiswaan & 6 & $5.3 \%$ \\
& Kepegawaian & 9 & $7.9 \%$ \\
& Keuangan & 7 & $6.1 \%$ \\
& Umum \& Perlengkapan & 25 & $20 \%$ \\
& Tidak diketahui & 34 & $31.6 \%$ \\
\hline Total & & $\mathbf{1 1 4}$ & $\mathbf{1 0 0} \%$ \\
\hline
\end{tabular}

Berdasarkan data pada tabel 1. dapat diketahui bahwa dari 114 karyawan yang menjadi subjek terdiri atas 69 karyawan laki-laki dan 45 karyawan perempuan, yang mana memiliki rentang usia antara 20 tahun hingga 57 tahun. Karyawan yang menjadi subjek penelitian ini meliputi tenaga kependidikan bagian administrasi yaitu divisi administrasi, akademik, kemahasiswaan, kepegawaian, keuangan, umum dan perlengkapan serta sebanyak 34 lainnya yang tidak diketahui divisi kerjanya.

Tabel 2

Deskripsi Statistik

\begin{tabular}{rrcc}
\hline Variabel & Statistik & Hipotetik & Empirik \\
\hline Kebosanan Kerja & Nilai Minimal & 21 & 25 \\
& Nilai Maksimal & 84 & 64 \\
& Mean $(\mu)$ & 52.5 & 40.89 \\
& Std. Deviasi $(\sigma)$ & 10.5 & 7.6 \\
\hline Perilaku & Nilai Minimal & 15 & 15 \\
Cyberloafing & Nilai Maksimal & 60 & 51 \\
& Mean $(\mu)$ & 37.5 & 26.67 \\
& Std. Deviasi $(\sigma)$ & 7.5 & 8.29 \\
\hline
\end{tabular}


Berdasarkan penghitungan skor hipotetik dan skor empirik dari data penelitian di atas (tabel 2) maka dapat diketahui gambaran dari masing-masing variabel. Tiap variabel dikategorikan menjadi 3 kategori, yaitu rendah, sedang, dan tinggi. Berikut hasil dari pengkategorian subjek penelitian:

Tabel 3

Kategorisasi Subjek Untuk Variabel Kebosanan Kerja dan Perilaku Cyberloafing

\begin{tabular}{llcc}
\hline Variabel & Kategori & Jumlah Subjek & $\mathbf{( \% )}$ \\
Kebosanan Kerja & Rendah $(\mathrm{x}<42)$ & 60 & $52.63 \%$ \\
& Sedang $(42 \leq \mathrm{x}<63)$ & 53 & $46.49 \%$ \\
& Tinggi $(63 \leq \mathrm{x})$ & 1 & $0.88 \%$ \\
\hline Total & & 114 & $100 \%$ \\
\hline Perilaku & Rendah $(\mathrm{x}<30)$ & 83 & $72.81 \%$ \\
Cyberloafing & Sedang $(30 \leq \mathrm{x}<45)$ & 28 & $24.56 \%$ \\
& Tinggi $(45 \leq \mathrm{x})$ & 3 & $2.63 \%$ \\
\hline Total & & 114 & $100 \%$ \\
\hline
\end{tabular}

Berdasarkan pengkategorian subjek (tabel. 3) dapat diketahui bahwa baik kebosanan kerja maupun perilaku cyberloafing karyawan bagian administrasi di Universitas X rata-rata berada pada kategori rendah.

\section{Uji Normalitas}

Sebelum dilakukan uji hipotesis terlebih dulu dilakukan uji asumsi klasik sebagai syarat analisis menggunakan teknik regresi linier sederhana. Salah satu asumsi yang harus terpenuhi adalah terkait distribusi data. Data yang memiliki distribusi normal yakni dengan nilai taraf signifikansi Kolmogorov-Smirnov > 0, 05. Berikut ini hasil uji normalitas data penelitian ini.

Tabel 4

Hasil Uji Normalitas

\begin{tabular}{ccc}
\hline Variabel & Signifikansi K-S & Keterangan \\
\hline Kebosanan Kerja & 0,696 & Sebaran normal \\
Perilaku Cyberloafing & 0,087 & Sebaran normal \\
\hline
\end{tabular}


Berdasarkan uji normalitas yang dilakukan diketahui nilai dari uji normalitas Kolmogorov-Smirnov baik skala kebosanan kerja maupun skala perilaku cyberloafing menunjukkan nilai signifikansi K-S > 0.05 dimana skala kebosanan kerja memiliki nilai K-S 0.696, sedangkan skala perilaku cyberloafing memiliki nilai K-S 0.087.Maka dapat disimpulkan bahwa data dari kedua skala dalam penelitian ini adalah berdistribusi normal.

\section{Uji Heterokedatisitas}

Dalam penelitian ini uji heterokedatisitas dilakukan menggunakan metode uji scatterplot dimana diketahui bahwa tidak terjadi heterokedatisitas dengan ditandai dengan tidak adanya pola-pola tertentu yang dibentuk dari titik-titik di scatterplot.

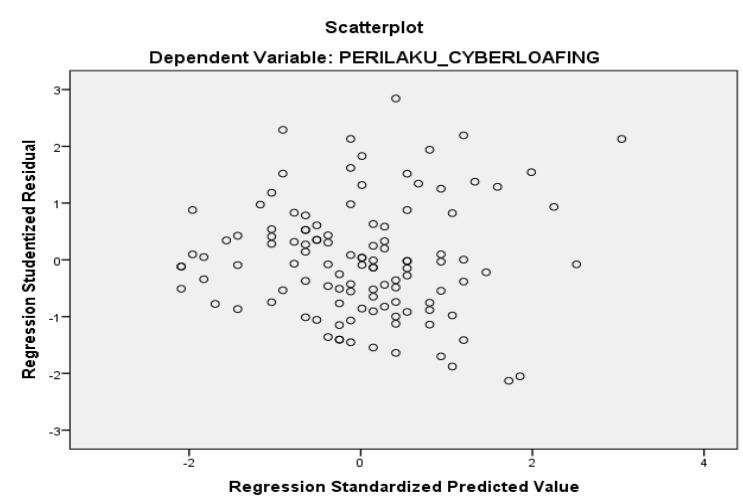

Gambar 1. Hasil Uji Heterokedatisitas

\section{Uji Linieritas}

Nilai linier ditentukan dengan melihat nilai signifikansi pada Deviation from Linierity. Jika nilai signifikansi $>0.05$ maka hubungan antar variabel adalah linier sedangkan jika $<0.05$ maka hubungan antar variabel adalah tidak linier.Tabel 5

Hasil Uji Linieritas

\begin{tabular}{cc}
\hline \multicolumn{2}{c}{ ANOVA Table } \\
\hline & Signifikansi \\
\hline $\begin{array}{c}\text { Kebosanan Kerja terhadap } \\
\text { Perilaku Cyberloafing }\end{array}$ & 0,186 \\
\hline
\end{tabular}


Berdasarkan hasil uji linieritas yang dilakukan diketahui bahwa nilai $\mathrm{p}=0.186$ dimana nilai tersebut lebih besar dari 0.05, maka dapat disimpulkan bahwa hubungan antar variabel penelitian adalah linier.

\section{Uji Hipotesis}

Dengan terpenuhinya uji asumsi klasik yang telah dilakukan, maka dilakukan uji hipotesis menggunakan analisis regresi linier sederhana dengan hasil sebagai berikut:

Tabel 6

Hasil Uji Hipotesis Analisis Regresi Sederhana

\begin{tabular}{cccc}
\hline $\mathbf{t}_{\text {hitung }}$ & $\mathbf{t}_{\text {tabel }}$ & Signifikansi & Keputusan \\
3.734 & 1.98 & 0.000 & Ha diterima \\
\hline
\end{tabular}

Hasil uji hipotesis diatas menunjukkan nilai Signifikansi $0.000(\mathrm{p}<0.05)$. Hal ini menunjukkan bahwa terdapat pengaruh yang signifikan antara kebosanan kerja terhadap perilaku cyberloafing, maka hipotesis dari penelitian ini diterima yaitu bahwa kebosanan kerja secara signifikan dapat berperan sebagai prediktor perilaku cyberloafing pada karyawan di Universitas X.Selain itu diketahui bahwa nilai $\mathrm{R}^{2}=0.111$. Angka tersebut menunjukkan besarnya prosentase sumbangan variabel bebas yaitu kebosanan kerja untuk mempengaruhi variabel terikat yaitu perilaku cyberloafing. Hasilnya adalah bahwa kebosanan kerja mempengaruhi perilaku cyberloafing yaitu sekitar 11.1\%, sedangkan 88.9\% lainnya dipengaruhi oleh faktor lain yang tidak dijelaskan dalam penelitian ini

\section{Analisis Tambahan}

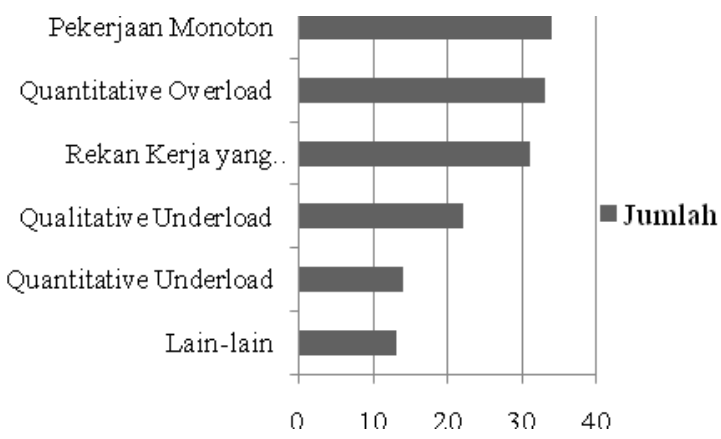

Gambar 2. Data Faktor Penyebab Kebosanan Kerja 
Berdasarkan gambar. 2 dapat dilihat faktor-faktor yang menyebabkan kebosanan kerja pada karyawan di Universitas X. Dari 114 orang tenaga kependidikan bidang administrasi sebanyak 34 orang karyawan menyatakan bahwa pekerjaan yang monoton merupakan faktor yang menyebabkan mereka mengalami kebosanan kerja, sedangkan 33 orang lainnya menyatakan bahwa beban kerja yang terlalu banyak atau quantitive overload menjadi faktor penyebab kebosanan kerja yang mereka alami.

Pada skala perilaku cyberloafing, peneliti juga menambahkan pertanyaan-pertanyaan untuk melihat kebutuhan penggunaan internet yang paling sering digunakan oleh tenaga kependidikan di Universitas $X$ dengan melihat frekuensi pemakaian dalam satu hari. Berikut data yang didapatkan.

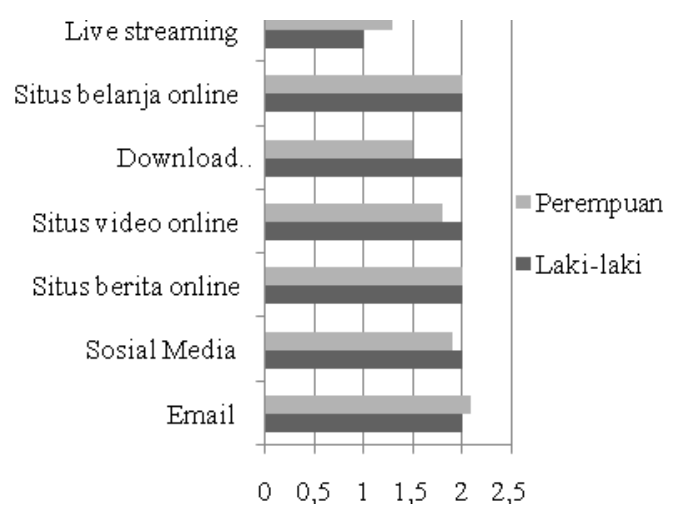

Gambar 3. Distribusi Frekuensi Penggunaan Internet

Berdasarkan gambar. 3 terlihat bahwa kebutuhan penggunaan internet karyawan di Universitas $X$ yang tidak berkaitan dengan pekerjaan memiliki rata-rata yang seragam. Ratarata karyawan dalam 1 hari membuka email pribadi, membuka situs sosial media, membuka situs berita online, membuka situs video online, mengunduh dokumen pribadi, dan mengunjungi situs belanja online 1 sampai dengan 2 kali dalam 1 hari. Sedangkan dalam 1 hari mereka tidak pernah atau 0 kali melakukan live streaming.

\section{Pembahasan}

Berdasarkan hasil uji hipotesis yang telah dilakukan (tabel 6), diketahui bahwa nilai signifikansi yaitu 0.000 ( $\mathrm{p}<0.05)$. Hal tersebut menunjukkan bahwa kebosanan kerja memiliki 
peran yang signifikan sebagai prediktor munculnya perilaku cyberloafing pada karyawan di Universitas $X$ sehingga hipotesis penelitian ini dinyatakan diterima.Hasil dari uji hipotesis ini sesuai dengan beberapa penelitian yang sebelumnya telah dilakukan mengenai kebosanan kerja dan perilaku cyberloafing. Seperti dalam penelitian Eastin, Glynn, dan Griffiths (2007) yang melihat bahwa karyawan yang mengalami kebosanan kerja yang tinggi akan terdorong untuk melakukan cyberloafing/ PWU (Personal Web Usage) sebagai salah satu cara untuk menghilangkan kebosanan yang dialami oleh karyawan tersebut.

Selain itu hasil penelitian ini juga menguatkan pendapat Liberman, Seidman, McKenna, dan Buffardi (2011) yang menyebutkan bahwa karyawan yang merasa bosan saat bekerja cenderung lebih mungkin untuk melakukan cyberloafing. Kegiatan-kegiatan seperti membuka email pribadi, membuka situs media sosial seperti facebook maupun twitter, menonton videovideo secara online, bahkan juga berbelanja online. Banyak hal yang dapat dilakukan oleh karyawan untuk menghilangkan rasa bosan akibat pekerjaan yang menumpuk, berulang, ataupun ketika tidak ada pekerjaan yang harus dilakukan.Menurut penelitian Lim dan Chen (2012) karyawan merasakan dampak positif ketika membuka laman hiburan (entertainment).Perilaku cyberloafing ini kemudian dijadikan sebagai salah satu strategi coping karyawan dalam menghadapi kebosanan akan pekerjaan yang monoton (Pindek dkk., 2018) maupun stress di tempat kerja (Andel, Kessler, Pindek, Kleinman, \& Spector, 2019).

Meskipun Aguenza, Al-kassem, Puad, dan Som (2012) menyebutkan bahwa penggunaan media sosial dapat meningkatkan produktivitas kerja dari karyawan, namun jika tidak dibatasi tentu akan memberikan dampak yang kurang baik bagi perusahaan seperti tertundanya penyelesaian tugas, jaringan internet menjadi tidak stabil, dan lain sebagainya. Selain berdampak pada perusahaan, ketidakmampuan karyawan untuk mengontrol perilaku cyberloading dapat berimbas pada meningkatnya kelelahan dan mengganggu kesehatan mental (Wu, Mei, Liu, \& Ugrin, 2020). Apalagi melihat bahwa tujuan dari penyediaan fasilitas internet tersebut tidak lain untuk mempermudah pekerjaan namun pada akhirnya menjadi salah satu hal yang membuat pekerjaan menjadi terbengkalai. Diperlukan kontrol diri yang baik agar dampak buruk dari perilaku cyberloafing ini tidak membuat karyawan semakin tidak produktif dalam bekerja. 
Hasil penelitian ini menunjukkan bahwa kebosanan kerja memiliki kontrubusi sebesar $11.1 \%\left(\mathrm{R}^{2}=0.111\right)$ sebagai faktor yang menyebabkan seorang karyawan melakukan cyberloafing sedangkan 88.9 persen dipengaruhi oleh faktor-faktor lainnya. Berdasarkan pengkategorian data kebosanan kerja maupun perilaku cyberloafing diketahui bahwa rata-rata kebosanan kerja dan perilaku cyberloafing karyawan di Universitas $X$ berada pada kategori rendah. Hal ini ditunjukkan dengan sebanyak 52.63 persen karyawan berada pada kebosanan kerja kategori rendah, sedangkan pada data perilaku cyberloafing diketahui bahwa sebanyak 72.81 persen karyawan juga berada pada kategori rendah. Begitu juga dengan perilaku cyberloafing yang ditunjukkan oleh karyawan yang berada dikategori rendah.

Menurut Workforce Boredom Index (Berry, 2006), karyawan administrasi memiliki tingkat kebosanan kerja yang lebih tinggi dibandingkan dengan karyawan bidang lain, namun data yang didapatkan menunjukkan bahwa kebosanan kerja tenaga kependidikan bagian administrasi di Universitas $X$ ini berada pada kategori rendah, artinya bahwa meskipun pekerjaan mereka monoton dan memiliki beban kerja yang banyak dan berpotensi menyebabkan mereka mengalami kebosanan kerja, namun faktor-faktor tersebut tidak cukup kuat untuk mendorong mereka mengalami kebosanan hingga pada kategori tinggi dimana kebosanan kerja pada kategori tersebut dapat menghalangi mereka dalam menyelesaikan tugas dan tanggung jawab kerja mereka.

Seorang karyawan yang mengalami kebosanan kerja dapat mengurangi atau bahkan menghilangkan kebosanan kerja yang dialami dengan mencari stimulus lain (Fisher, 1993). Mereka dapat melakukan kegiatan-kegiatan lain seperti membaca novel, mengobrol dengan rekan kerja, menggunakan fasilitas perusahaan, dan lain sebagainya. Kebosanan kerja karyawan bagian administrasi di Universitas $X$ yang berada pada kategori rendah disebabkan oleh faktor pekerjaan yang monoton dan beban kerja yang banyak dapat mendorong karyawan untuk melakukan cyberloafing sebagai salah satu cara untuk menghilangkan kebosanan kerja yang mereka alami, namun pada kenyataannya perilaku cyberloafing dari karyawan bagian administrasi di Universitas $X$ juga berada pada kategori rendah. Hal ini didukung dengan temuan penelitian S dan Cahyadin (2012) yang menyebutkan bahwa semakin tinggi beban kerja karyawan maka kemungkinan seorang karyawan untuk menunjukkan perilaku 
cyberloafing juga akan semakin meningkat jika diimbangi dengan kemampuan penggunaan internet yang cukup.

Menurut Sumantri dan Suharmono (2011), Indonesia memiliki budaya nasional yang kolektif dimana terdapat hubungan yang dekat antara karyawan dengan keluarga dan rekan kerjanya yang mana berbeda dengan negara-negara barat lain yang memiliki budaya individualism yang tinggi. Budaya kolektif yang ada di Indonesia ini dapat menjadi salah satu faktor eksternal lainnya yang menyebabkan perilaku cyberloafing karyawan bagian administrasi di Universitas $X$ berada pada kategori rendah. Adanya kedekatan hubungan antara karyawan dengan rekan kerja menyebabkan ketika mereka mengalami kebosanan kerja mereka lebih memilih mencari stimulus lain yaitu berupa mengobrol dengan rekan kerja dibandingkan mengakses situs-situs internet di sela-sela waktu kerja mereka. Karyawan bagian administrasi di Universitas $X$ merasa bahwa mereka memiliki beban pekerjaan yang banyak sehingga memungkinkan mereka tidak memiliki cukup waktu untuk dapat melakukan cyberloafing sebagai cara menghilangkan kebosanan kerja sehingga perilaku cyberloafing karyawan bagian administrasi di Universitas $\mathrm{X}$ juga berada pada kategori rendah.

Sebagaimana yang disebutkan sebelumnya bahwa 88.9 persen dari perilaku cyberloafing dipengaruhi oleh faktor-faktor lain. Beberapa faktor lain tersebut diantaranya seperti yang dijelaskan oleh Askew dkk. (2014) yakni salah satunya yang menyebabkan karyawan melakukan cyberloafing adalah kemampuan dari karyawan tersebut untuk mengontrol perilaku mereka ditempat kerja. Hal tersebut dapat dilihat dari bagaimana mereka dapat menahan diri untuk tidak melakukan cyberloafing ketika mereka dihadapkan pada kebebasan dan kurangnya kontrol perusahaan terhadap penggunaan internet.

\section{Kebutuhan Penggunaan Internet Karyawan}

Faktor lainnya menurut Ozler dan Polat (2012)kebiasaan dan adiksi internet dapat menjadi salah satu penyebab seorang karyawan melakukan cyberloafing. Berdasarkan data tambahan yang didapatkan menunjukkan bahwa karyawan Universitas $X$ rata-rata mengakses situs-situs yang tidak berkaitan dengan pekerjaannya 1 - 2 kali dalam 1 hari (gambar 3), artinya bahwa kegiatan mereka untuk mengakses internet pada saat jam kerja tersebut menjadi suatu 
kebiasaan dan menyebabkan mereka melakukan penyalahgunaan penggunaan internet tiap harinya.Sedangkan untuk perilaku cyberloafing lainnya yaitu melakukan live streaming acara televisi maupun radio online tidak banyak karyawan yang melakukan cyberloafing bentuk tersebut setiap harinya. Situs yang banyak diakses oleh karyawan pada saat jam kerja setiap harinya adalah situs email, situs belanja online, dan situs video online seperti youtube.com.

\section{Faktor Penyebab Kebosanan Kerja}

Data lain yang ditemukan dalam penelitian ini adalah bahwa rata-rata karyawan bagian administrasi di Universitas $\mathrm{X}$ merasa bahwa pekerjaan yang monoton dan beban kerja yang terlalu banyak menjadi faktor penyebab mereka mengalami kebosanan kerja (gambar 2). Hasil penelitian ini menguatkan penelitian-penelitian sebelumnya yang menyebutkan bahwa pekerjaan yang monoton dan berulang dapat mendorong karyawan mengalami kebosanan kerja (Bruursema, Kessler, \& Spector, 2011; Fisher, 1993). Kebosanan akibat pekerjaan yang monoton tersebut rentan dialami oleh karyawan-karyawan administratif dimana dalam penelitian ini adalah tenaga kependidikan di Universitas X. Seperti yang diketahui bahwa tenaga kependidikan di universitas memiliki tugas-tugas yang telah dikhususkan di tiap divisi kerja. Contohnya untuk bagian akademik, mereka memiliki tugas seperti menginput nilai mahasiswa, melakukan rekap absensi, dan lain sebagainya. Tugas-tugas tersebut dilakukan setiap hari sehingga menyebabkan mereka mengalami kebosanan kerja.

\section{Kesimpulan}

Pengujian hipotesis menggunakan uji regresi linier sederhana menunjukkan nilai thitung lebih besar dari tabel $(3.734>1.98)$ dengan nilai signifikansi yaitu $0.000(\mathrm{p}<0.05)$. Jadi dapat disimpulkan bahwa kebosanan kerja secara signifikan dapat berperan sebagai prediktor perilaku cyberloafing pada karyawan di Universitas X. Berdasarkan data tambahan lain ditemukan bahwa faktor yang mendorong karyawan di Universitas X mengalami kebosanan kerja adalah karakteristik pekerjaan yang monoton dan beban kerja yang terlalu banyak (quantitative overload). Rata-rata karyawan di Universitas X melakukan cyberloafing 1 hingga 2 
kali dalam satu hari yaitu meliputi membuka email pribadi dan situs hiburan lain (media sosial, youtube, berita online, online shop).

Saran

Adapun saran yang dapat diberikan untuk penelitian selanjutnya adalah untuk melihat kebosanan kerja maupu perilaku cyberloafing pada pekerjaan-pekerjaan yang memiliki karakteristik berbeda dengan yang ada dalam penelitian ini. Selain itu disarankan kepada peneliti yang ingin melakukan penelitian dengan subjek yang sama pada Universitas lainnya untuk melakukan kontrol saat pembagian skala sehingga tiap bagian kerja atau divisi dapat terwakili dan data tersebut dapat digunakan untuk melihat perbedaan kebosanan kerja dan perilaku cyberloafing di bagian kerja atau divisi.

\section{Referensi}

Aguenza, B. B., Al-kassem, A. H., Puad, A., \& Som, M. (2012). Social Media and Productivity in the Workplace: Challenges and Constraints 1, 2.

Andel, S. A., Kessler, S. R., Pindek, S., Kleinman, G., \& Spector, P. E. (2019). Is Cyberloafing More Complex Than We Originally Thought? Cyberloafing As A Coping Response To Workplace Aggression Exposure. Computers in Human Behavior, 101, 124-130.

Askew, K., Buckner, J. E., Taing, M. U., Ilie, A., Bauer, J. A., \& Coovert, M. D. (2014). Explaining Cyberloafing: The Role Of The Theory Of Planned Behavior. Computers in Human Behavior, 36, 510-519.

Berry, M. (2006, Juli 27). Boredom Index Puts HR Just Behind Accountancy As Exciting Graduate Career Option. Diambil 18 Mei 2020, dari Personnel Today website: https://www.personneltoday.com/hr/boredom-index-puts-hr-just-behind-accountancyas-exciting-graduate-career-option/

Bruursema, K., Kessler, S. R., \& Spector, P. E. (2011). Bored Employees Misbehaving: The Relationship Between Boredom And Counterproductive Work Behaviour. Work \& Stress, 25(2), 93-107.

Eastin, M. S., Glynn, C. J., \& Griffiths, R. P. (2007). Psychology Of Communication Technology Use In The Workplace. Cyberpsychology \& Behavior: The Impact of the Internet, Multimedia and Virtual Reality on Behavior and Society, 10(3), 436-443.

Fisher, C. D. (1993). Boredom At Work: A Neglected Concept. Human Relations, 46(3), 395-417.

Harju, L. K., Hakanen, J. J., \& Schaufeli, W. B. (2014). Job boredom and its correlates in 87 Finnish organizations. Journal of occupational and environmental medicine.

Hawley, C. F. (2005). 201 Cara Untuk Mendorong Setiap Karyawan Berkinerja Bintang. Jakarta: Penerbit Erlangga. 
Hooff, M. L. M. van, \& Hooft, E. A. J. van. (2017). Boredom At Work: Towards A Dynamic Spillover Model Of Need Satisfaction, Work Motivation, And Work-Related Boredom. European Journal of Work and Organizational Psychology, 26(1), 133-148.

Kartika, B. (2014, Desember 2). Baidu Indonesia: 74,7 Persen Pengakses Mobile Internet Adalah Laki-Laki. Diambil 18 Mei 2020, dari Tech in Asia Indonesia website: https://id.techinasia.com/baidu-indonesia-smartphone-akses-internet-mobile

KOMINFO, P. (2014). Kemkominfo: Pengguna Internet Di Indonesia Capai 82 Juta. Diambil 4 Maret 2020, dari Website Resmi Kementerian Komunikasi dan Informatika RI website: https://kominfo.go.id:443/index.php/content/detail/3980/Kemkominfo\%3A+Pengguna+I nternet+di+Indonesia+Capai+82+Juta/0/berita_satker

KOMINFO, P. (2017). Penetrasi Internet 2017 Naik, Pengguna Masih Dominan di Wilayah Urban. Diambil 5 Maret 2020, dari Website Resmi Kementerian Komunikasi dan Informatika RI website: https://kominfo.go.id:443/content/detail/12644/penetrasiinternet-2017-naik-pengguna-masih-dominan-di-wilayah-urban/0/berita_satker

Liberman, B., Seidman, G., McKenna, K. Y. A., \& Buffardi, L. E. (2011). Employee Job Attitudes And Organizational Characteristics As Predictors Of Cyberloafing. Computers in Human Behavior, 27(6), 2192-2199.

Lim, V. K. G. (2002). The IT Way Of Loafing On The Job: Cyberloafing, Neutralizing And Organizational Justice. Journal of Organizational Behavior, 23(5), 675-694.

Lim, V. K. G., \& Chen, D. J. Q. (2012). Cyberloafing At The Workplace: Gain Or Drain On Work? Behaviour E Information Technology, 31(4), 343-353.

Lim, V. K. G., \& Teo, T. S. H. (2005). Prevalence, Perceived Seriousness, Justification And Regulation Of Cyberloafing In Singapore: An Exploratory Study. Information $\mathcal{E}$ Management, 42(8), 1081-1093.

Mael, F., \& Jex, S. (2015). Workplace Boredom: An Integrative Model Of Traditional And Contemporary Approaches. Group E Organization Management, 40(2), 131-159.

Munandar, A. S. (2011). Psikologi Industri dan Orgaisasi. Jakarta: Penerbit Universitas Indonesia.

Ozler, D. E., \& Polat, G. (2012). Cyberloafing Phenomenon In Organizations: Determinants And Impacts. International Journal of eBusiness and eGovernment Studies, 4(2), 1-15.

Pindek, S., Krajcevska, A., \& Spector, P. E. (2018). Cyberloafing As A Coping Mechanism: Dealing With Workplace Boredom. Computers in Human Behavior, 86, 147-152.

Reijseger, G., Schaufeli, W. B., Peeters, M. C. W., Taris, T. W., Beek, I. van, \& Ouweneel, E. (2012). Watching The Paint Dry At Work: Psychometric Examination Of The Dutch Boredom Scale. Anxiety, Stress, and Coping, 26(5), 508-525.

S, H. S. R., \& Cahyadin, M. (2012). The Moderation Effect Of Commitment To Supervisor And Internet Expertise On Work Stressor And Employee Cyberloafing: The Study On Employee Of Local Government Of Surakarta. Journal of Indonesian Economy and Business, $27(2), 271-284$.

Schaufeli, W. B., \& Salanova, M. (2014). Burnout, Bredom And Engagement In Theworkplace. In Peeters, M.C.W., de Jonge, J., \& Taris, T.W. (Eds.), An introduction tocontemporary work psychology. West Sussex: John Wiley \& Sons, Ltd.

Sumantri, S., \& Suharmono. (2011). Kajian Proposisi Hubungan Antara Dimensi Budaya Nasional Dengan Motivasi Dalam Suatu Organisasi Usaha. 28. 
Wu, J., Mei, W., Liu, L., \& Ugrin, J. C. (2020). The Bright And Dark Sides Of Social Cyberloafing: Effects On Employee Mental Health In China. Journal of Business Research, 112, 56-64.

\begin{tabular}{|l|l|l|l|l|}
\hline Submit & Review & Revisi & Diterima & Publis \\
\hline 06-03-2020 & 29-04-2020 sd 06-05-2020 & 19-05-2020 & 04-06-2020 & 08-07-2020 \\
\hline
\end{tabular}

\section{Fatiya Halum Husna \\ Institut Agama Islam Negeri (IAIN) Tulungagung \\ Ika Adita Silviandari, Ika Rahma Susilawati \\ Universitas Brawijaya}

Email : fatiyahalum@iain-tulungagung.ac.id 